\title{
Phylogenetic signal of orbicules at family level: Rubiaceae as case study
}

\author{
Brecht Verstraete, ${ }^{1}$ Inge Groeninckx, ${ }^{1}$ Erik Smets $^{1,2}$ \& Suzy Huysmans ${ }^{1}$ \\ 1 Laboratory of Plant Systematics, K.U. Leuven, Kasteelpark Arenberg 31, P.O. Box 2437, 3001 Leuven, Belgium \\ 2 Netherlands Centre for Biodiversity Naturalis, Leiden University, P.O. Box 9517, 2300 RA Leiden, The Netherlands \\ Author for correspondence: Brecht Verstraete,brecht.verstraete@bio.kuleuven.be
}

\begin{abstract}
Orbicules are tiny a-cellular sporopollenin structures that occur in the anthers of many angiosperms together with the pollen grains. Although their occurrence is common, little is known about their function and systematic usefulness. With regard to orbicules, Rubiaceae (Gentianales) are the most intensively studied plant family and therefore an ideal case to present the evolution and phylogenetic signal of orbicule characters at family level. The occurrence and morphology of orbicules was investigated in 64 species of Rubiaceae using scanning electron microscopy. Five relevant orbicule features (presence/absence, abundance, size, shape, ornamentation) were optimized onto a custom-made phylogeny of the family. By optimizing the five orbicule characters some evolutionary trends can be observed. The previously suggested trend in angiosperms towards orbicule absence in more derived taxa is confirmed for Rubiaceae. Orbicules appear to have been independently lost at least nine times within the family, with two subsequent reversals. Small orbicules represent the plesiomorphic character state for the family. A trend from spherical towards irregular orbicules is observed, while ornamented orbicules occur only in derived lineages. Orbicule characters are constant at generic level and in most cases at tribal level, and therefore have potential for systematics. The presence of orbicules is correlated with the occurrence of a non-amoeboid tapetum.
\end{abstract}

Keywords evolutionary trends; orbicules; phylogenetic signal; Rubiaceae; tapetum; Ubisch bodies

\section{INTRODUCTION}

In the present era, morphological data no longer play the primary role in reconstructing phylogenies of plant groups. Thanks to the accelerated generation of sequences from many independently evolving molecular markers, most phylogenetic questions may be answered by using molecular data only (Wiens, 2004). However, the evaluation of morphological characters as potential synapomorphies can give additional support in the reconstruction of the tree of life where molecular studies fall short (Endress, 2003). This is especially true for micromorphological characters associated with fertilization such as pollen morphology and ultrastructure (Blackmore, 2007). Since the pioneering work of Erdtman (1952), the systematic usefulness of pollen characters has been shown at different levels, e.g., distinction of eudicots by 3 -aperturate pollen (Furness \& Rudall, 2004), and in different taxonomic groups, e.g., Cyperaceae (Nagels \& al., 2009), Lamiaceae (Moon \& al., 2008a, b) and Rubiaceae (Dessein \& al., 2005).

In anthers of flowering plants, tiny (usually $<1 \mu \mathrm{m}$ ) a-cellular structures may occur on the inner tangential and radial walls of tapetal cells. These granules are called orbicules (Erdtman \& al., 1961) or Ubisch bodies (Rowley, 1962). As generally accepted, we here consider these two terms to be synonyms, although some authors do make a distinction (Abadie \& Hideux, 1979). Orbicules originate as lipid droplets, called pro-orbicules, inside the rough endoplasmatic reticulum of parietal tapetal cells (Echlin \& Godwin, 1968; Risueño \& al., 1969). After exocytosis at the tetrad stage, the pro-orbicules remain attached to the inner tangential and radial walls of the tapetal cells and are coated with sporopollenin, simultaneously with the growing pollen exine (Echlin, 1971; Christensen \& al., 1972). The surface ornamentation of the orbicule often resembles that of the pollen sexine (Hesse, 1986), reflecting the expression of the same genes in the tapetum and the microspore cytoplasm (Christensen \& al., 1972). Although several hypotheses about the function of orbicules were put forward, the exact role of these structures is still unknown (Huysmans $\&$ al., 1998). Recently, their distribution in angiosperms has been reviewed (S. Huysmans, unpub.). This review demonstrates that orbicules are found in all large (informal) groups in angiosperms such as magnoliids, monocots, basal eudicots, rosids and asterids.

The orbicules in angiosperms vary in abundance, size, shape and ornamentation. With regard to orbicules, Rubiaceae (the largest family of Gentianales) is the most thoroughly studied family of the angiosperms. This, combined with the availability of a global phylogenetic framework (Robbrecht \& Manen, 2006; Bremer \& Eriksson, 2009), makes Rubiaceae an ideal case for a detailed study of the evolution of orbicule characters at family level. Some preliminary work on the systematic value of orbicules in the family has been done (Huysmans \& al., 1997; Vinckier \& al., 2000), but a general overview of the evolutionary trends is lacking. Some of these characters have been systematically analysed in several other taxa of Gentianales such as Apocynaceae s.l. (Vinckier \& Smets, 2002c), Gentianaceae (Vinckier \& Smets, 2003) and Loganiaceae s.l. (Vinckier $\&$ Smets, 2002a). The overall conclusion for Gentianales was that orbicules are a common feature and that their characters can be informative at tribal level (Vinckier \& Smets, 2002b).

The present study has two major aims: (1) to document the presence and morphology of orbicules in all major 
evolutionary lineages of Rubiaceae, and (2) to investigate the evolution and systematic usefulness of orbicule characters throughout the family.

\section{- MATERIALS AND METHODS}

This study is mainly based on herbarium material, supplemented with living material. Sixty-four species of Rubiaceae were selected for molecular and morphological examination (Appendix). The sampling was designed to cover all the different tribes recognized in Rubiaceae (Bremer \& Eriksson, 2009). All 44 tribes, except Cremasporeae, Gaertnereae, Hillieae, Isertieae, Putorieae, Retiniphylleae, Schradereae, Sipaneeae and Theligoneae are represented by at least one genus. The 64 original observations for this study are combined with all previously known orbicule data of Rubiaceae in the discussion of the evolutionary trends.

Preparation of the plant material. - The anthers of herbarium specimens were dissected from the flowers when possible. In case of small anthers the whole flower was collected. The dried material was rehydrated in wetting agent Agepon (Agfa Gevaert, Leverkusen, Germany) for at least 12 hours in order to restore the natural morphology. Following dehydration in a graded acetone series $(33 \%-50 \%-70 \%-90 \%-100 \%)$, the material was critical-point dried (Leica EM CPD030, BAL-TEC AG, Balzers, Liechtenstein) and mounted on stubs using doublesided adhesive tape. The pollen grains were carefully removed from the open locules using a fine cactus spine. This facilitates the observation of orbicules on the inner locule surface.

Anthers of fresh flowers were dehydrated immediately after collection in 2,2-dimethoxypropane (DMP) following Halbritter (1998) for a maximum of 24 hours. Prior to criticalpoint drying the material was rinsed in $100 \%$ acetone for 15 minutes. The next steps in the preparation were identical to those described above.

The stubs were sputter-coated with gold for 120 seconds (Sputter Coater, SPI Supplies, West Chester, Pennsylvania, U.S.A.). The observations of the prepared anthers were done using a scanning electron microscope (JSM 6360, Jeol Ltd., Tokyo, Japan) at $15 \mathrm{kV}$. All measurements were performed on scanning electron micrographs using Carnoy v.2.0 (Schols \& al., 2002).

Phylogenetic analysis. - For the investigation of the evolution of orbicule characters in Rubiaceae, we used a custommade phylogeny of the family that best fits our sampling. The analysis is based on a data matrix of atpB-rbcL, petD and $\operatorname{trnL}$-trnF sequences, which is designed to cover nearly all tribes recognized in Rubiaceae (I. Groeninckx, unpub.). Six species of Gentianales and Solanales were designated as outgroup (Atropa belladonna, Ceropegia linearis, Gentiana dinarica, Nicotiana tabacum, Sphenoclea zeylanica, Strychnos potatorum). The dataset comprises 3790 characters, of which 724 are parsimony-informative.

Equally weighted parsimony analyses were done using NONA v.2.0 (Goloboff, 1999) launched through WinClada v.1.0 (Nixon, 2002). Heuristic searches for the shortest trees were performed using the parsimony ratchet (Nixon, 1999).
Traditional searches were repeatedly conducted using TBR on 1000 Wagner trees constructed with random addition of taxon sequences, holding 10 trees per search and expending the memory to conduct more thorough analyses holding up to 10,000 trees ( 10 times h 100,000 mu*1000 h/10 max*). Ratchet runs of 200 iterations each, holding one tree per iteration and randomly weighting $10 \%$ of the potentially informative characters were carried out until the most-parsimonious trees (MPTs) were repeatedly found. All trees were collected, unambiguously supported branches collapsed, duplicate trees were identified and removed. A total of 26 MPTs $(\mathrm{L}=2146$, consistency index $\mathrm{CI}=0.54$, retention index $\mathrm{RI}=0.79$ ) were repeatedly found, and used to calculate a strict consensus tree $(\mathrm{L}=2158, \mathrm{CI}=0.53, \mathrm{RI}=0.79)$. In order to evaluate the relative support of the clades, jackknife (JS) and bootstrap (BS) analyses were executed using 1000 replicates with 100 initial trees holding one tree per random addition, doing TBR to hold 1000 trees and calculating a consensus on each repetition. Frequency values above $65 \%$ were plotted onto the consensus of the MPTs.

We investigated the distribution of orbicules and the evolution of their characters by optimizing the morphological character states onto the consensus tree from the parsimony analysis using WinClada v.1.0 (Nixon, 2002). A comparative study of orbicule distribution in flowering plants (S. Huysmans, unpub.) demonstrated that at generic level the variation for the orbicule characters is extremely low. Therefore, extrapolation of the data to generic level seems justified.

Previously published molecular trees were also used in order to test whether the resulting evolutionary trends change depending on which topology is used (results not shown). Because this was not the case and our conclusions remain the same, it seems justified only to show the custom-made phylogeny.

\section{- RESULTS}

Orbicules appear to be a common feature in Rubiaceae: 40 of the 64 species examined have orbicules (Table 1). In 21 species no orbicules were present (Fig. 1G-H). Orbicule occurrence in three species-Danais aurantiaca, Pentagonia tinajita and Pseudomussaenda flava - is unclear. Here, small structures in low abundance and without distinct ornamentation are embedded in residual tapetal material. Possibly these structures may represent artefacts by the preparation method. Nevertheless, we do suggest the presence of orbicules in these three species but further research should confirm these observations. Presence of orbicules is the plesiomorphic character state and at least nine shifts towards absence of orbicules have occurred: four in the subfamily Ixoroideae (supertribe Ixoridinae sensu Robbrecht \& Manen, 2006) and five in the subfamily Rubioideae (Fig. 4). In the latter subfamily two reversals back to orbicule presence happened in Psychotria and Serissa. Variations in orbicule abundance, size, shape, ornamentation and their association with each other and the locule wall are also observed. For each species studied, information on orbicule morphology is summarized in Table 1. 
Table 1. Occurrence and morphology of orbicules in Rubiaceae. O, orbicules; +, present; -, absent; ?, unclear. Abundance: a, abundant; s, scattered; va, very abundant. Size: minimum-(mean)-maximum. Shape: do, doughnut-shaped; irr, irregular; sph, spherical. Ornamentation: me, microechinate; $\mathrm{mg}$, microgranulate; perf, perforate; ps, psilate; $\approx$, the orbicule ornamentation is similar to the pollen wall ornamentation. Association: agg, aggregated; conn, connected via threads; em, embedded; netw, the orbicules form a network.

\begin{tabular}{|c|c|c|c|c|c|c|c|}
\hline Taxon & $\mathrm{O}$ & Abundance & Size $(\mu \mathrm{m})$ & Shape & Ornamentation & Association & Fig. \\
\hline Afrocanthium keniense & - & - & - & - & - & - & \\
\hline Anthospermum pachyrrhizum & + & $\mathrm{a}$ & $0.93-(1.06)-1.18$ & sph & ps & conn & $1 \mathrm{~B}, 3 \mathrm{C}$ \\
\hline Antirhea borbonica var. duplidivisa & + & va & $0.49-(0.66)-0.72$ & $\mathrm{sph}$ & $\mathrm{mg}$ & $\mathrm{em}$ & \\
\hline Bertiera angusiana & + & $\mathrm{a}$ & $1.53-(1.80)-2.37$ & irr & rough & agg, em & $1 \mathrm{~F}$ \\
\hline Breonadia salicina & + & va & $0.92-(0.99)-1.10$ & irr & rough & agg & \\
\hline Calycophyllum candidissimum & + & va & $0.48-(0.62)-0.78$ & irr & rough & agg & \\
\hline Chamaepentas hindsioides & + & va & $0.36-(0.40)-0.44$ & irr & $\mathrm{mg}$ & - & $2 \mathrm{E}$ \\
\hline Chassalia cristata & - & - & - & - & - & - & \\
\hline Chiococca alba & + & va & 0.89-(0.95)-1.09 & irr & me, perf, $\approx$ & - & $2 \mathrm{~A}$ \\
\hline Cinchona calisaya & + & va & $0.33-(0.39)-0.47$ & $\mathrm{sph}$ & ps & agg & \\
\hline Coccocypselum guianense & + & va & $0.48-(0.55)-0.62$ & do & ps & - & \\
\hline Coffea stenophylla & + & va & $0.28-(0.41)-0.51$ & irr & rough & - & \\
\hline Colletoecema dewevzei & - & - & - & - & - & - & \\
\hline Coprosma tenuifolia & + & va & $0.66-(0.80)-1.24$ & do & ps & agg & $3 \mathrm{~A}$ \\
\hline Craterispermum caudatum & - & - & - & - & - & - & \\
\hline Cremaspora triflora & + & a & $0.60-(0.67)-0.72$ & irr & rough & - & \\
\hline Cubanola domingensis & + & va & $1.08-(1.21)-1.32$ & $\mathrm{sph}$ & $\mathrm{me}, \approx$ & - & $2 \mathrm{G}, 2 \mathrm{H}$ \\
\hline Danais aurantiaca & $+?$ & - & - & - & - & - & \\
\hline Didymosalpinx abbeokutae & + & va & $0.62-(0.76)-1.19$ & irr & rough, perf & - & $2 \mathrm{~F}$ \\
\hline Empogona kirkii subsp. junodii & + & $\mathrm{a}$ & $0.76-(0.93)-1.08$ & irr & rough & - & \\
\hline Euclinia longiflora & - & - & - & - & - & - & \\
\hline Exostema longiflorum & + & va & $1.11-(1.43)-1.65$ & irr & me, perf, $\approx$ & - & \\
\hline Galium ossirwaense var. ossirwaense & - & - & - & - & - & - & \\
\hline Gardenia jasminoides & - & - & - & - & - & - & \\
\hline Geophila afzelii & - & - & - & - & - & - & $1 \mathrm{H}$ \\
\hline Guettarda speciosa & + & va & $0.54-(0.70)-0.88$ & do & ps & agg & \\
\hline Hamelia patens & + & a & $0.53-(0.69)-0.79$ & do & ps & agg & \\
\hline Hoffmannia refulgens & + & va & $0.70-(0.81)-0.90$ & irr & me, perf, $\approx$ & - & \\
\hline Hymenodictyon floribundum & + & a & $0.61-(0.66)-0.75$ & do & ps & agg & $2 \mathrm{C}$ \\
\hline Ixora borboniae & + & va & $0.86-(0.98)-1.29$ & irr & rough & conn & $3 \mathrm{D}$ \\
\hline Ixora finlaysoniana & + & va & $0.45-(0.53)-0.62$ & irr & rough & - & $1 \mathrm{C}$ \\
\hline Kraussia floribunda & + & a & $0.57-(0.70)-0.87$ & irr & rough & agg & \\
\hline Luculia gratissima & + & va & $0.44-(0.48)-0.55$ & $\mathrm{sph}$ & ps & $\mathrm{em}$ & $2 \mathrm{~B}$ \\
\hline Mitriostigma axillare & - & - & - & - & - & - & \\
\hline Morinda citrifolia & - & - & - & - & - & - & \\
\hline Mussaenda polita & + & va & $0.19-(0.22)-0.26$ & sph & ps & agg & $1 \mathrm{D}$ \\
\hline Mycetia malayana & - & - & - & - & - & - & \\
\hline Oldenlandia corymbosa & - & - & - & - & - & - & \\
\hline Ophiorrhiza mungos & - & - & - & - & - & - & \\
\hline Oxyanthus unilocularis & - & - & - & - & - & - & \\
\hline Paederia cruddasiana subsp. cruddasiana & - & - & - & - & - & - & $1 \mathrm{G}$ \\
\hline Pauridiantha coalescens & + & $\mathrm{a}$ & $0.26-(0.30)-0.38$ & $\mathrm{sph}$ & ps & - & \\
\hline Payera sp. & + & va & $0.36-(0.44)-0.54$ & irr & $\mathrm{mg}, \approx$ & netw & $3 \mathrm{E}$ \\
\hline
\end{tabular}


Table 1. Continued.

\begin{tabular}{|c|c|c|c|c|c|c|c|}
\hline Taxon & $\mathrm{O}$ & Abundance & Size $(\mu \mathrm{m})$ & Shape & Ornamentation & Association & Fig. \\
\hline Pentagonia tinajita & $+?$ & - & - & - & - & - & \\
\hline Posoqueria latifolia & + & va & $0.40-(0.48)-0.54$ & $\mathrm{sph}$ & ps & agg & \\
\hline Psychotria kirkii & + & s & $0.44-(0.55)-0.70$ & do & ps & - & \\
\hline Randia sp. & - & - & - & - & - & - & \\
\hline Rondeletia purdiei & + & va & $0.34-(0.38)-0.48$ & do & ps & agg & \\
\hline Rubia cordifolia subsp. conotricha & - & - & - & - & - & - & \\
\hline Sabicea venosa & - & - & - & - & - & - & \\
\hline Saldinia boiviniana & + & s & $0.65-(0.81)-0.96$ & sph & ps & em & \\
\hline Schumanniophyton magnificum & + & va & $0.84-(1.03)-1.29$ & irr & rough & $\mathrm{em}$ & \\
\hline Stipularia africana & - & - & - & - & - & - & \\
\hline Tarenna gracilis & + & va & $0.54-(0.64)-0.74$ & irr & rough, perf, $\approx$ & - & \\
\hline Triainolepis africana subsp. hildebrandtii & + & va & $0.18-(0.25)-0.31$ & irr & $\mathrm{mg}, \approx$ & netw & $3 \mathrm{~F}$ \\
\hline Uncaria africana & + & va & $0.47-(0.65)-0.90$ & sph & ps & agg & \\
\hline Vangueria agrestis & - & - & - & - & - & - & \\
\hline Virectaria procumbens & - & - & - & - & - & - & \\
\hline Warszewiczia coccinea & + & va & 0.77-(0.98)-1.19 & irr & rough & $\mathrm{em}$ & $3 \mathrm{~B}$ \\
\hline
\end{tabular}

Abundance. - Comparing abundance of orbicules between samples is justified since only mature flowers are observed. Orbicules are a-cellular and cannot divide, which means their quantity on the inner locule wall does not change after the degeneration of the tapetum. We distinguished three categories, as follows: "scattered": visible locule surface area larger than the surface covered by orbicules; "abundant": orbicules cover a large part of the locule wall, but are not touching each other; "very abundant": locule surface almost invisible due to the orbicules. In only $7 \%$ of the species with orbicules they occur scattered, e.g., in Serissa japonica (Fig. 1A). In 23\% of the species with orbicules they are abundant, e.g., in Anthospermum pachyrrhizum (Fig. 1B). In the majority (70\%) of the species with orbicules, e.g., Ixora finlaysoniana (Fig. 1C), they are very abundant. Orbicules are always in close contact with the tapetal membrane and never occur on the pollen grains.

Optimization demonstrates that "very abundant" represents the plesiomorphic character state in Rubiaceae (Fig. 5A). Two reductions towards abundant orbicules occurred in the subfamily Cinchonoideae (supertribe Cinchonidinae, Robbrecht \& Manen, 2006) and three shifts in the subfamily Ixoroideae (supertribe Ixoridinae, Robbrecht \& Manen, 2006). Only in the subfamily Rubioideae three shifts towards scattered orbicules have occurred, besides three shifts towards abundant orbicules.

Size. - The mean size of orbicules ranges from $0.22 \mu \mathrm{m}$ in Mussaenda polita (Fig. 1D) to $1.95 \mu \mathrm{m}$ in Razafimandimbisonia humblotii (Fig. 1E). Within a specimen orbicule size may vary. The smallest intraspecific variation is observed in Mussaenda polita (Fig. 1D), with a range from 0.19 to $0.26 \mu \mathrm{m}$. In Bertiera angusiana (Fig. 1F), the largest variation is found with orbicule size ranging from 1.53 to $2.37 \mu \mathrm{m}$. Aggregated or embedded orbicules were often difficult to measure. We therefore used three size classes $(<0.5 \mu \mathrm{m}, 0.5-1.0 \mu \mathrm{m},>1.0 \mu \mathrm{m})$ to optimally represent most of the size variation. Because only few samples have orbicules larger than $1 \mu \mathrm{m}$, steps of half a micrometer instead of one micrometer were used.

Small orbicules $(<0.5 \mu \mathrm{m})$ represent the plesiomorphic character state in the family (Fig. 5B). The subfamily Cinchonoideae (supertribe Cinchonidinae) are characterized by medium-sized orbicules $(0.5-1.0 \mu \mathrm{m})$, nevertheless two shifts towards larger orbicules $(>1 \mu \mathrm{m})$ occurred as well as two reversals. In the subfamily Ixoroideae (supertribe Ixoridinae), we observed two shifts towards medium-sized orbicules, three shifts towards large, and one reversal back to small orbicules in Coffea. The character evolution within subfamily Rubioideae is more complex: a shift towards medium-sized orbicules is followed by a reversal back to small ones in the more derived taxa of the subfamily. In Anthospermeae a second shift towards medium-sized orbicules happened, followed by a shift towards large orbicules in Anthospermum.

Shape. - In the species investigated three distinct orbicule shapes are present: (1) irregular (e.g., Chiococca alba, Fig. 2A), (2) spherical (e.g., Luculia gratissima, Fig. 2B) and (3) 

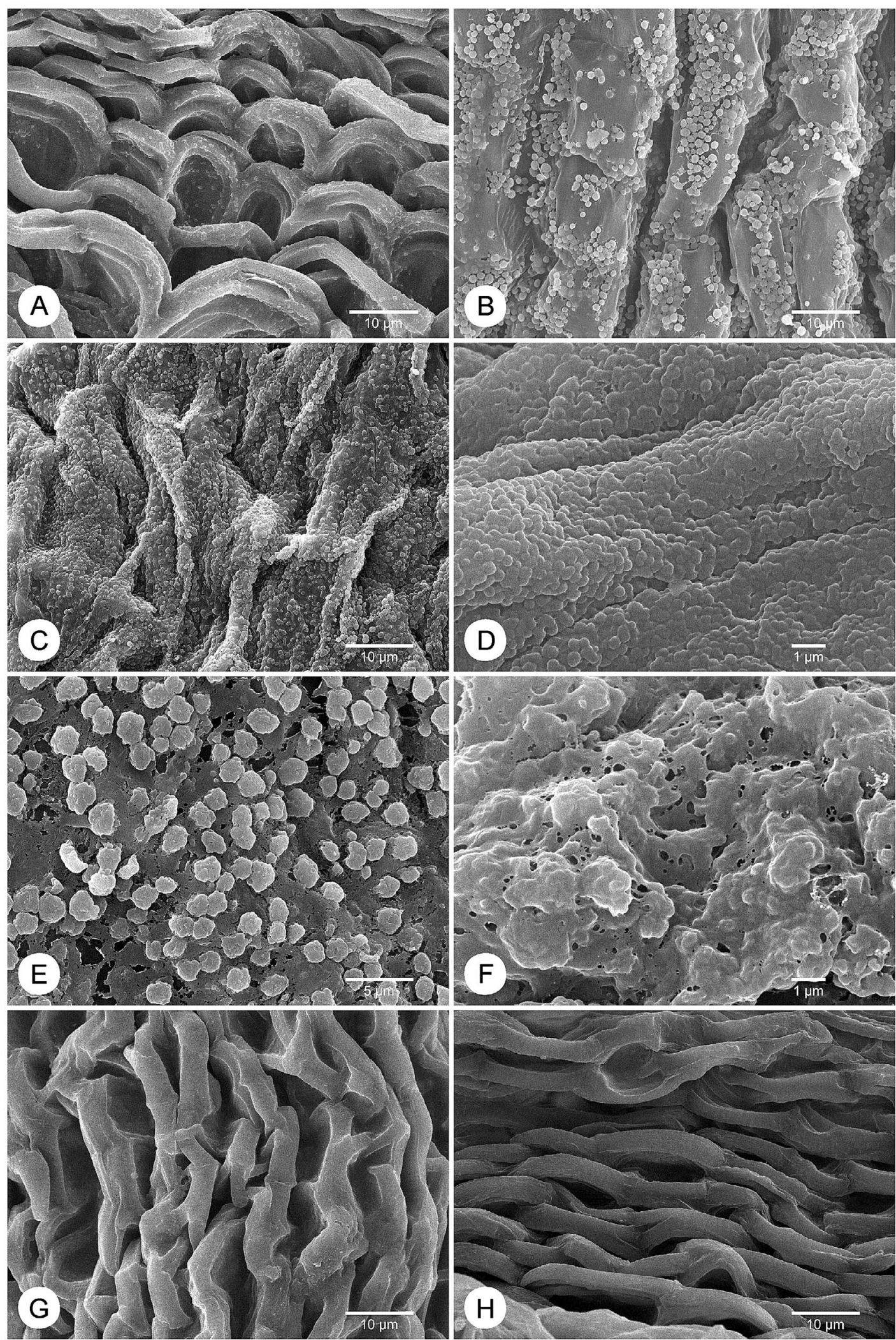

Fig. 1. SEM pictures of orbicules in Rubiaceae showing presence/absence and variation in abundance and size. A, Serissa japonica: orbicules scattered; B, Anthospermum pachyrrhizum: orbicules abundant; C, Ixora finlaysoniana: orbicules very abundant; D, Mussaenda polita: smallest orbicules and smallest intraspecific variation in size; E, Razafimandimbisonia humblotii: largest orbicules; $\mathbf{F}$, Bertiera angusiana: largest intraspecific variation in size; G, Paederia cruddasiana subsp. cruddasiana: orbicules lacking, note ridges of endothecium cells; $\mathbf{H}$, Geophila afzelii: orbicules lacking, note the ridges of endothecium cells. 

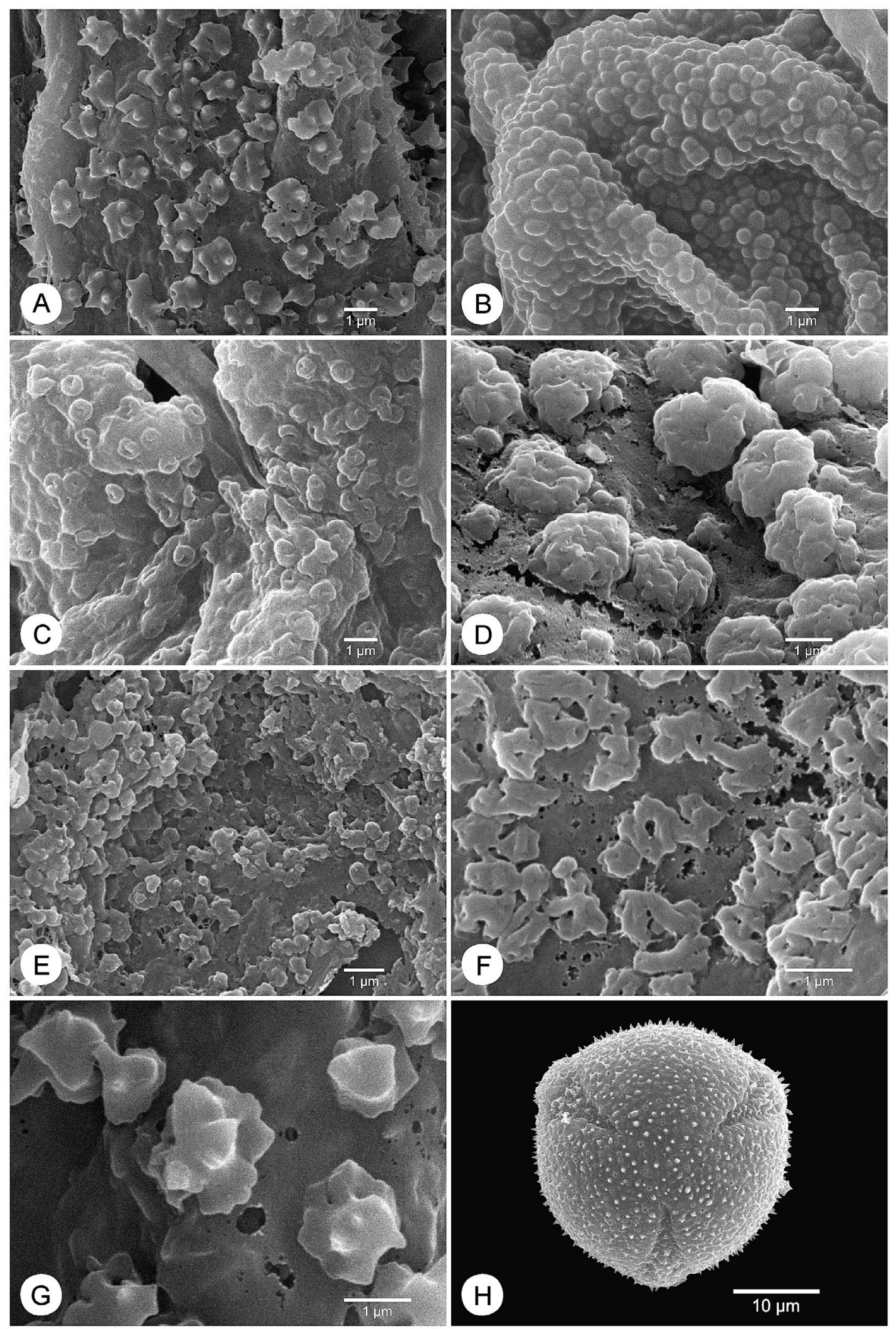

Fig. 2. SEM pictures of orbicules in Rubiaceae showing variation in shape and ornamentation. A, Chiococca alba: irregular shaped orbicules; B, Luculia gratissima: spherical orbicules with psilate ornamentation; C, Hymenodictyon floribundum: doughnut-shaped orbicules; D, Razafimandimbisonia humblotii: orbicules with rough surface; E, Chamaepentas hindsioides: orbicules with microgranules; F, Didymosalpinx abbeokutae: orbicules with central perforation; G, Cubanola domingensis: orbicules with microspines; $\mathbf{H}$, Cubanola domingensis: pollen grain with microspines. 
rounded oblate with a central indentation (doughnut-shaped, e.g., Hymenodictyon floribundum, Fig. 2C). More than half of the species $(54 \%)$ have irregular orbicules, one fourth $(26 \%)$ have spherical ones and the remaining species $(20 \%)$ have doughnut-shaped orbicules.

Spherical orbicules represent the plesiomorphic character state in the family (Fig. 5C). Cinchonoideae (supertribe Cinchonidinae) are characterized by doughnut-shaped orbicules. Four shifts towards irregular orbicules occurred as well as four reversals back to spherical ones. The situation in Ixoroideae (supertribe Ixoridinae) is relatively simple: two shifts towards irregular orbicules occurred. For Rubioideae, we observed four shifts towards doughnut-shaped, two shifts towards irregular and one reversal back to spherical orbicules in Anthospermum.

Ornamentation. - Four different character states are recognized in the ornamentation of orbicules: (1) psilate (smooth, Luculia gratissima, Fig. 2B), (2) rough (e.g., Razafimandimbisonia humblotii, Fig. 2D), (3) microgranulate (with microgranules, e.g., Chamaepentas hindsioides, Fig. 2E) and (4) microechinate (with microspines, e.g., Cubanola domingensis, Fig. 2G). The terms are adopted from Punt \& al. (2007). The term "rough" is used when the orbicule surface is not smooth, but has no distinct ornamentation pattern either.
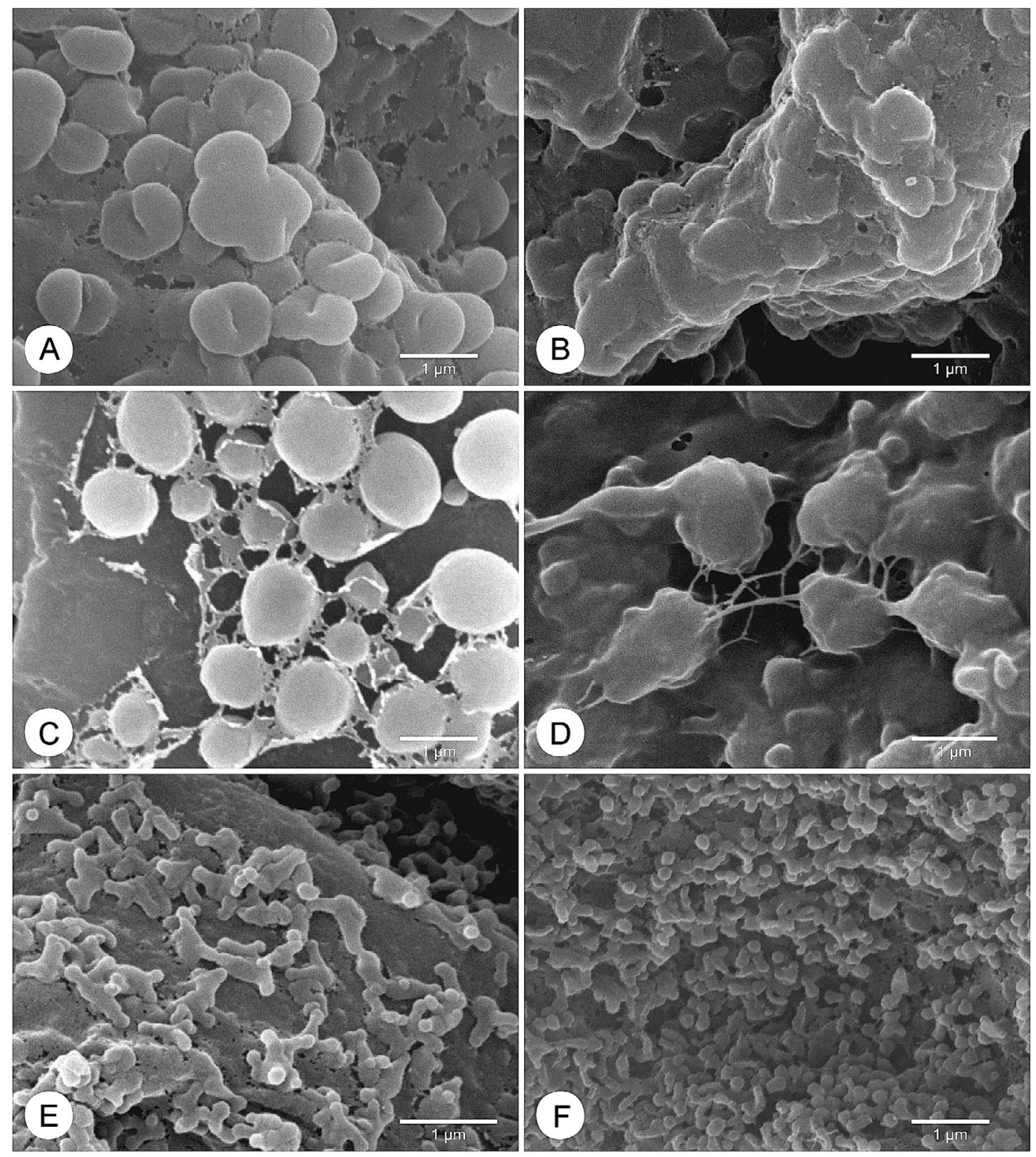

Fig. 3. SEM pictures of orbicules in Rubiaceae showing association of orbicules with each other and the locule wall. A, Coprosma tenuifolia: orbicules aggregated; B, Warszewiczia coccinea: orbicules embedded in tapetal remnants; C Anthospermum pachyrrhizum: orbicules interconnected by small threads; D, Ixora borboniae: orbicules interconnected by small threads; E, Payera sp.: network of connected orbicules; F, Triainolepis africana subsp. hildebrandtii: network of connected orbicules. 


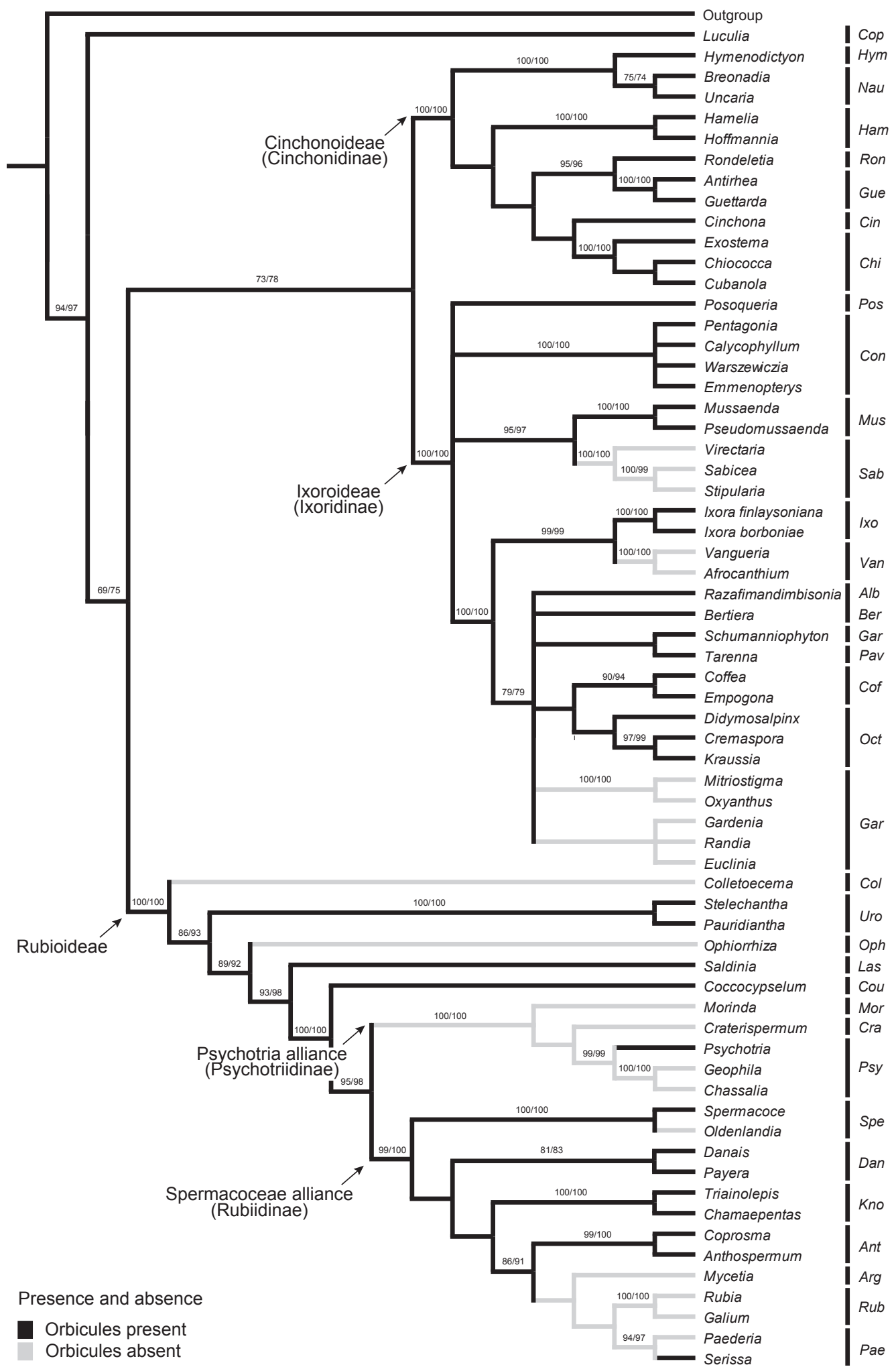

Fig. 4. Presence and absence of orbicules optimized on the strict consensus tree of Rubiaceae based on maximum parsimony analysis of atpB$r b c L$, petD and $\operatorname{trnL}$-trnF showing bootstrap/jackknife support values above the branches. Names according to Bremer \& Eriksson (2009) and names between brackets according to Robbrecht \& Manen (2006). Alb, Alberteae; Ant, Anthospermeae; Arg, Argostemmateae; Ber, Bertiereae; Chi, Chiococceae; Cin, Cinchoneae; Cof, Coffeeae; Col, Colletoecemateae; Con, Condamineeae; Cop, Coptosapelteae; Cou, Coussareeae; Cra, Craterispermeae; Dan, Danaideae; Gar, Gardenieae; Gue, Guettardeae; Ham, Hamelieae; Hym, Hymenodictyeae; Ixo, Ixoreae; Kno, Knoxieae; Las, Lasiantheae; Mor, Morindeae; Mus, Mussaendeae; Nau, Naucleeae; Oct, Octotropideae; Oph, Ophiorrhizeae; Pae, Paederieae; Pav, Pavetteae; Pos, Posoquerieae; Psy, Psychotrieae; Ron, Rondeletieae; Rub, Rubieae; Sab, Sabiceeae; Spe, Spermacoceae; Uro, Urophylleae; Van, Vanguerieae. 
Psilate orbicules are the dominant feature in Rubiaceae and occur in $40 \%$ of the species investigated. One third of the species (33\%) have rough orbicules, some have microgranulate orbicules (14\%) and a few have microspines on the surface $(13 \%)$. Sometimes a central perforation can be found in the orbicule wall, e.g., Didymosalpinx abbeokutae (Fig. 2F). In several species a striking analogy between the ornamentation of the orbicule wall and that of the pollen sexine occurs. In $\mathrm{Cu}$ banola domingensis the microspines of the orbicules resemble the spines of the pollen sexine (Fig. 2G-H).

Orbicules with a smooth or psilate surface represent the plesiomorphic character state of Rubiaceae (Fig. 5D). In Cinchonoideae (supertribe Cinchonidinae) two shifts towards microechinate orbicules occurred, one towards microgranules and one towards rough orbicules. In Ixoroideae (supertribe Ixoridinae) there are two shifts to rough orbicules. In Rubioideae we noted two shifts towards microgranulate, one shift towards microechinate and two reversals back to psilate orbicules.

Association of orbicules with each other and the locule wall. - Aggregated orbicules occur in more than one third of the species investigated, e.g., Coprosma tenuifolia (Fig. 3A). In six species the orbicules are embedded in residual tapetal material, e.g., Warszewiczia coccinea (Fig. 3B). Anthospermum pachyrrhizum (Fig. 3C) and Ixora borboniae (Fig. 3D) have orbicules that are interconnected by small threads. In Payera sp. (Fig. 3E) and Triainolepis africana (Fig. 3F), although belonging to the different tribes Danaideae and Knoxieae, a special arrangement is found: the orbicules are elongated and branched, which results in connected orbicules. Optimizing these characters is not relevant because different associations can occur in the same specimen.

\section{DISCUSSION}

Rubiaceae are the most extensively studied family of angiosperms concerning orbicule presence. A review of major palynological characters and their phylogenetic signal in Rubiaceae was published by Dessein \& al. (2005). This study also mentioned orbicules but only summarized the known literature. The present study adds data on 64 Rubiaceae species, of which 43 possess orbicules and 21 lack them (Table 1). This sampling size might seem limited in order to thoroughly investigate evolutionary trends of orbicule morphology. However, the present study analyses different orbicule characters on a purposely built phylogeny rendering it the most extensive study at family level to date. In addition to the phylogenetic perspective, tested in this paper by the optimization of the presence/absence of orbicules in Rubiaceae, we integrate our results with literature data to provide an overall picture of orbicule distribution within Rubiaceae. For convenience of comparison, we extrapolate the morphological data from species level to generic level when optimizing the character states on the topology.

Trends in orbicule presence/absence. - The presence of orbicules clearly represents a plesiomorphic character for angiosperms since orbicules are common in the ANITA clades and positive observations are reported in ferns and gymnosperms as well (Huysmans \& al., 1998). A recent study investigated the presence/absence of orbicules in Annonaceae and it was found that the distribution pattern reflects the general pattern observed in flowering plants: orbicules are a plesiomorphic feature, common in the early diverging lineages with a trend towards orbicule absence in the more derived clades (Huysmans $\&$ al., 2010). The same trend is also found at family level in Rubiaceae by the occurrence of orbicules in Luculia, which has a basal position in the family tree, and the absence of orbicules in the more derived clades (Fig. 4).

Our results indicate that the entire subfamily Cinchonoideae (supertribe Cinchonidinae, Robbrecht \& Manen, 2006) is characterized by the presence of orbicules. This conclusion is also supported by the results in Dessein \& al. (2005). However, Verellen \& al. (2007) claimed that some species in the subfamily lack orbicules, i.e., species of the tribes Hymenodictyoneae and Naucleeae. Hymenodictyon floribundum has distinct doughnut-shaped orbicules (Fig. 2C) but other, previously investigated Hymenodictyon species do not seem to have orbicules (Verellen \& al., 2007). The same apparent discrepancy also occurs in Breonadia and Uncaria, two genera in the tribe Naucleeae. According to Verellen \& al. (2007) this last tribe holds much variation in orbicule presence but there is still constancy at the generic level.

Within the subfamily Ixoroideae (supertribe Ixoridinae, Robbrecht \& Manen, 2006) orbicules are entirely lacking in the tribes Sabiceeae and Vanguerieae. In Gardenieae both positive and negative observations are made and we observed in two unresolved clades the same shift towards orbicule absence. The tribe is considered paraphyletic (Robbrecht \& Manen, 2006; Bremer \& Eriksson, 2009) and this is confirmed by our results. The present study shows orbicule presence for Coffeeae although some negative observations were recorded by Vinckier $\&$ al. (2000). Nevertheless, orbicule presence is constant at generic level in this tribe. All other tribes in the subfamily Ixoroideae (supertribe Ixoridinae, Robbrecht \& Manen, 2006) are characterized by the presence of orbicules. This indicates that orbicules have a predictive value within the tribal level.

In the subfamily Rubioideae orbicules were lost several times during evolution, i.e., in two tribes of the basal Rubioideae, in the Psychotria alliance (supertribe Psychotriidinae, Robbrecht \& Manen, 2006) and in the derived clades of the Spermacoceae alliance (supertribe Rubiidinae, Robbrecht \& Manen, 2006). In this study and in all previous studies on orbicules in Rubiaceae, the largest number of negative observations are recorded in this subfamily. According to Huysmans \& al. (2003) orbicules are absent in Rubieae (see also Dessein \& al., 2005). In Paederieae occurrence of orbicules varies, with orbicules being present in Serissa and absent Paederia. It should be noted that orbicules are very tiny and scarce in Serissa, possibly representing a final stage towards complete absence of orbicules. In Psychotrieae we observed a reversal back to orbicule presence only in the genus Psychotria, other genera lacking orbicules. However, following the classification of Robbrecht \& Manen (2006), genera without orbicules all belong to the tribe Palicoureeae, a segregate tribe sister to Psychotrieae. Then, Psychotrieae would be homogeneous in terms of 
Fig. 5. Orbicule characters optimized on the strict consensus tree of Rubiaceae based on maximum parsimony analysis of $a t p B-r b c L$, petD and trnL-trnF showing bootstrap/ jackknife support values above the branches. A, Abundance of orbicules; B, size of orbicules; C, shape of orbicules; D, ornamentation of orbicules.

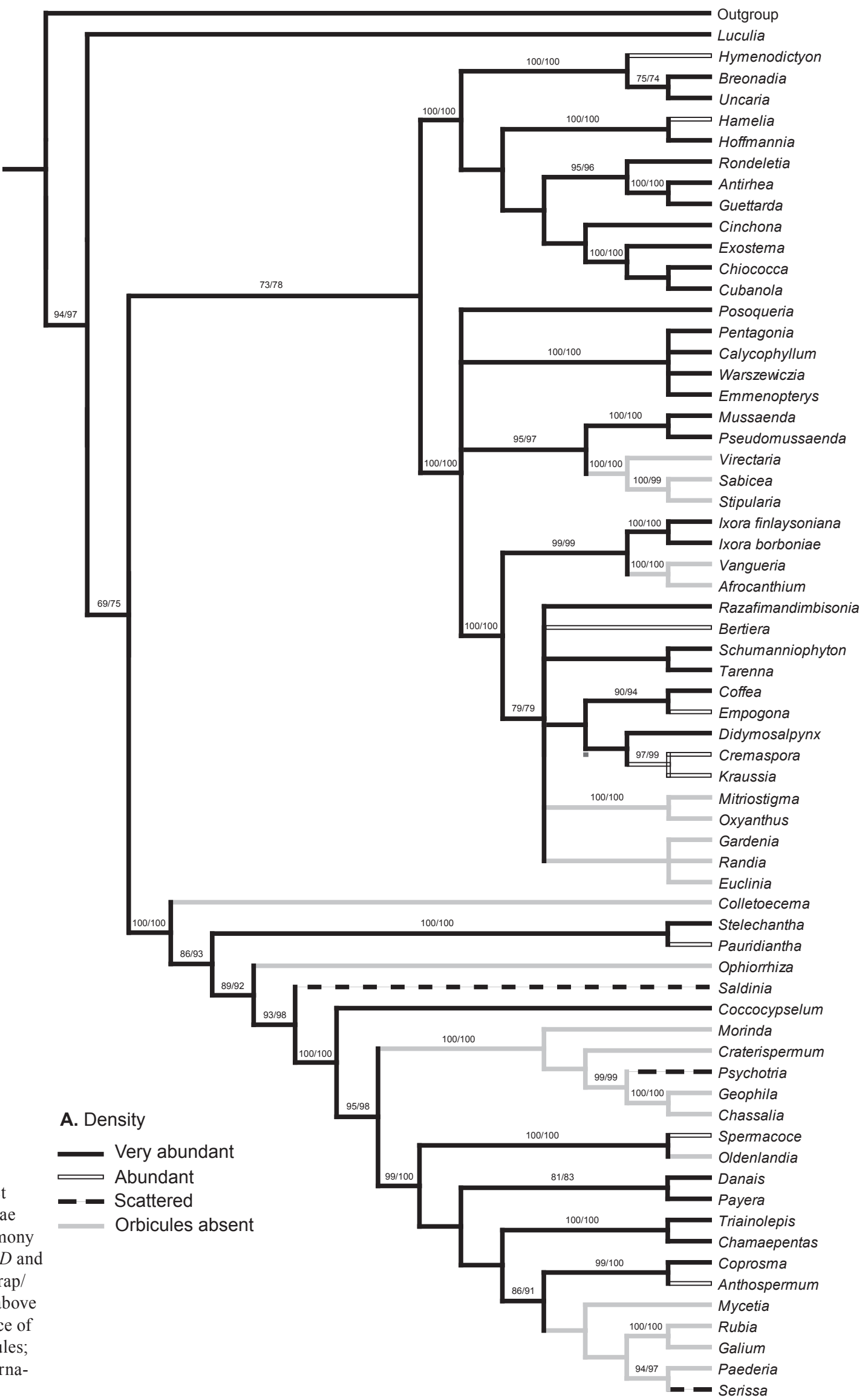




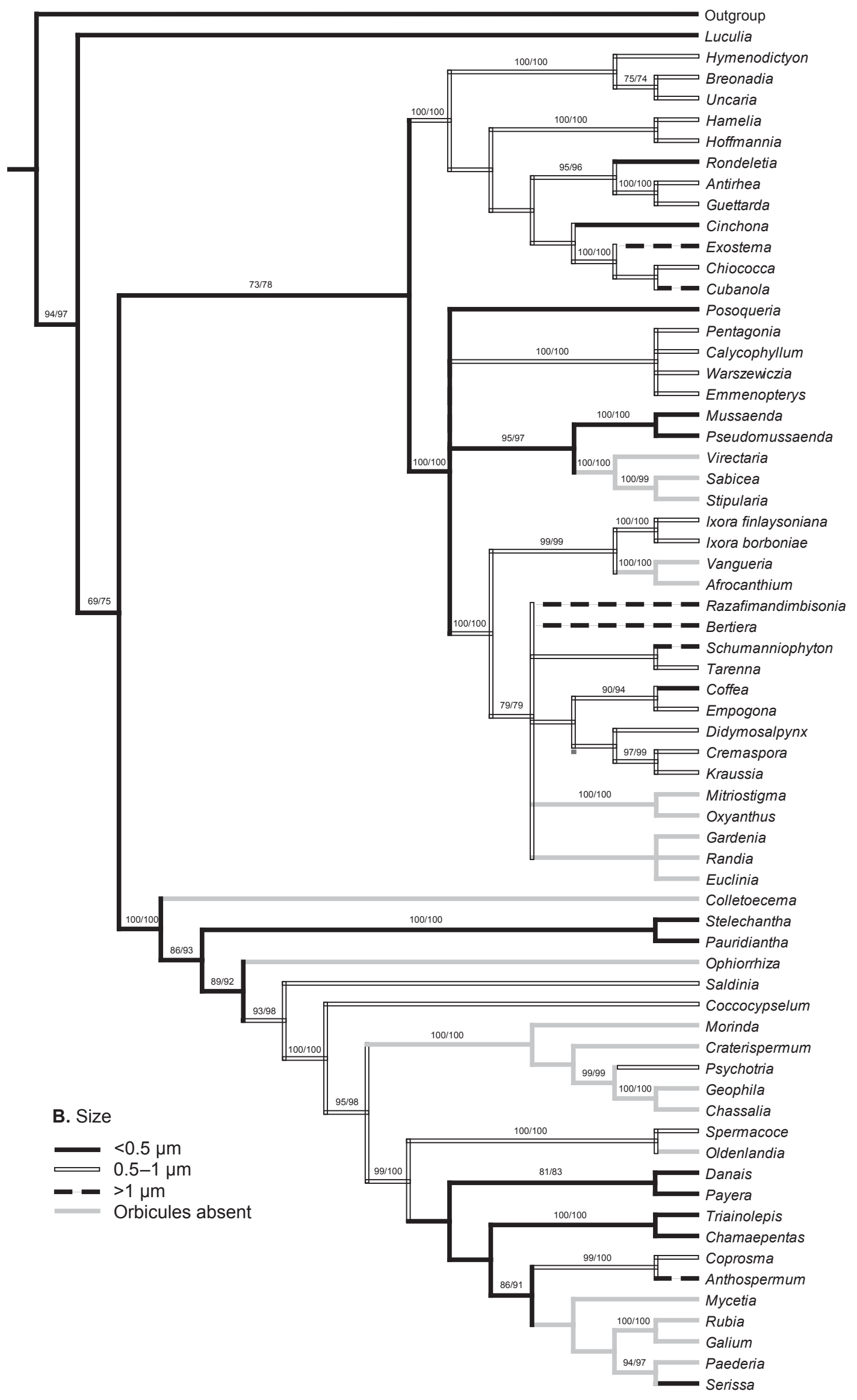




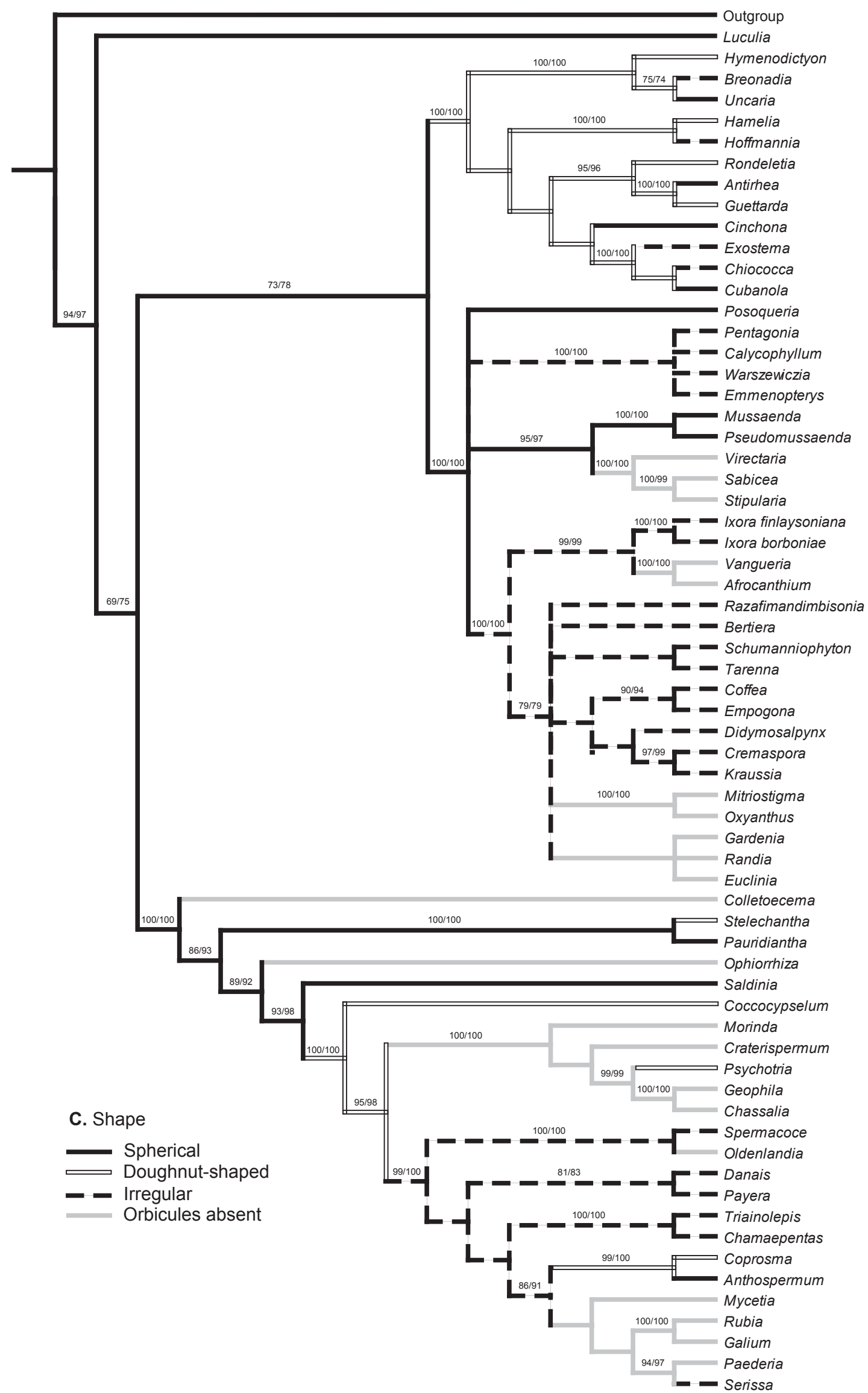




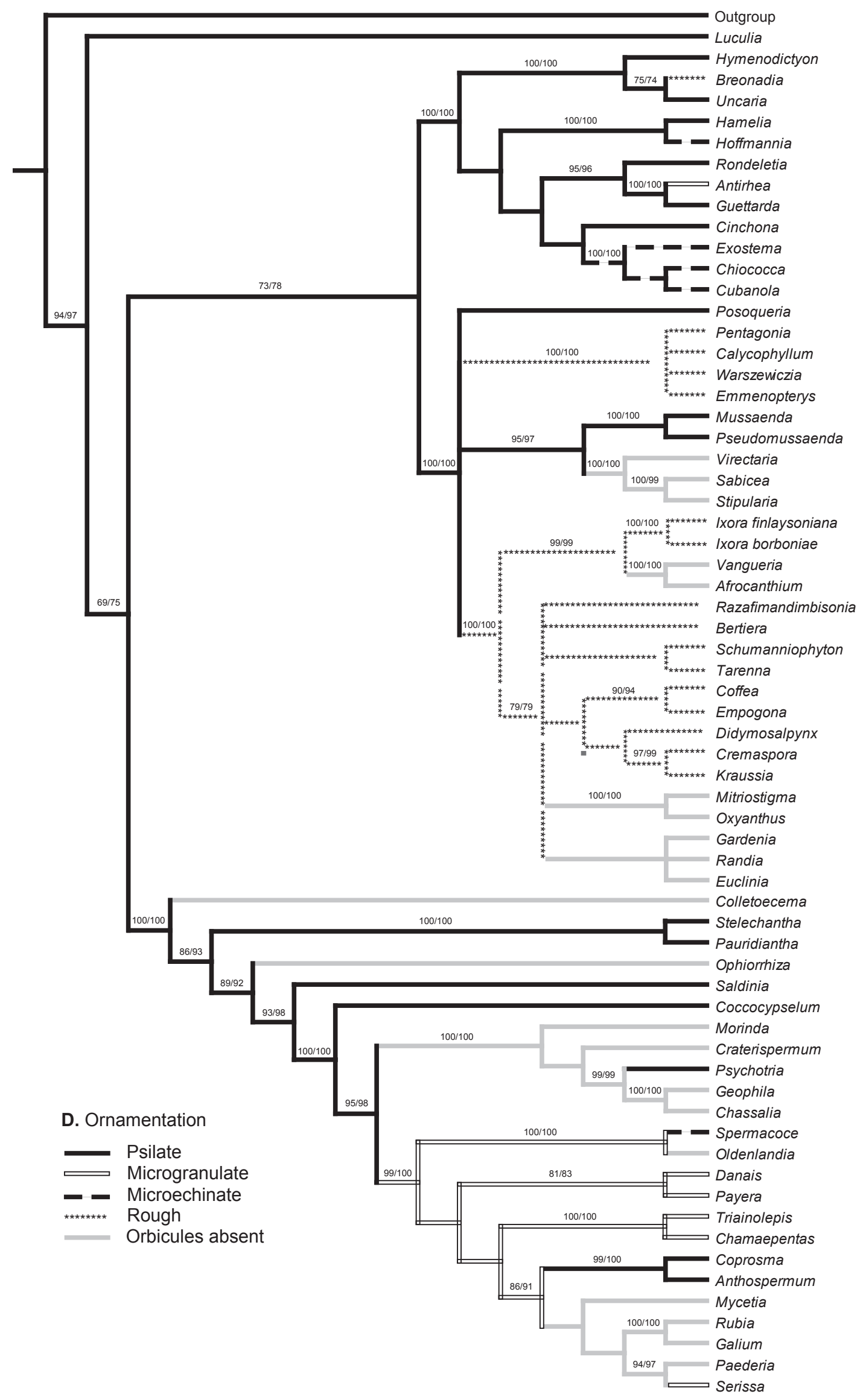


orbicule presence. Spermacoceae, finally, are more heterogeneous, with most genera lacking orbicules except Spermacoce (Galati, 2003; this study). More detailed studies on presence and absence of orbicules within Spermacoceae could elucidate the phylogenetic signal of orbicules in this tribe. Nevertheless, the constancy of this characters at generic level still holds true.

Only in 5 out of 165 genera investigated, intrageneric variation was observed: Breonadia (Verellen \& al., 2007 vs. this study), Coptosapelta (Verellen \& al., 2004), Hymenodictyon (Verellen \& al., 2007 vs. this study), Psychotria (Huysmans \& al., 1998 vs. this study) and Uncaria (Verellen \& al., 2007 vs. this study). In Verellen \& al. $(2004,2007)$ it was mentioned that it was often difficult to ascertain the presence or absence of distinct orbicules. In contrast to our findings, Huysmans \& al. (1998) did not find any orbicules in Psychotria kirkii. Unfortunately this negative observation can not be verified because there are no pictures provided. To resolve these contradictory results and to determine the generic stability of the orbicule characters, we suggest investigating several specimens. The constant presence of orbicules in $97 \%$ of Rubiaceae genera studied so far and its constancy at generic level in the whole of the angiosperms (S. Huysmans, unpub.), suggest that orbicules can have a predictive value at generic level. This constancy can be extrapolated to tribal level in Cinchonoideae and Ixoroideae as there is little or no variation of orbicule presence in the tribes. In Rubioideae, orbicule characters seem to be constant in most tribes, with variation occurring in Paederieae and Spermacoceae. Constancy at tribal level is in agreement with the findings of Vinckier \& Smets (2002b) for the other families in Gentianales. The available evidence strongly indicates that there is an evolutionary trend towards the absence of orbicules in the more derived taxa of Rubiaceae.

Phylogenetic signal of orbicule characters. - As shown in Fig. 5A, orbicules are very abundant in taxa representing early divergent clades of all subfamilies. At least eight transitions to abundant and three shifts to scattered are observed, all occurring in the more derived lineages. Our data strongly suggest an evolutionary trend towards a reduction of the number of orbicules per surface area unit.

Plotting the size of orbicules on the phylogeny indicates that a small mean diameter $(<0.5 \mu \mathrm{m})$ is the plesiomorphic character state (Fig. 5B). The outgroup species have small orbicules (for data see Vinckier \& Smets, 2002b) and for Rubiaceae this state is represented by the early diverged Luculia (Fig. 2B). The more derived species have larger orbicules, e.g., Anthospermum pachyrrhizum $(1.06 \mu \mathrm{m})$ (Fig. 1B). When following the supratribal level proposed by Robbrecht \& Manen (2006), an increase in orbicule size towards the more derived taxa is detected, except for the supertribe Rubiidinae (Spermacoceae alliance sensu Bremer \& Eriksson, 2009).

Concerning orbicule shape, spherical orbicules obviously represent the plesiomorphic character state for Rubiaceae (Fig. 5C). Orbicules of the more derived taxa are no longer symmetrical: the subfamily Cinchonoideae (supertribe Cinchonidinae, Robbrecht \& Manen, 2006) is characterized by doughnutshaped orbicules, while the subfamily Ixoroideae (supertribe Ixoridinae, Robbrecht \& Manen, 2006) and the Spermacoceae alliance (supertribe Rubiidinae, Robbrecht \& Manen, 2006) have a trend towards irregularly shaped orbicules. Despite the fact that three distinct shapes are defined, it is sometimes difficult to assign one of these states to the orbicules observed. Because of their small dimensions, the orbicule ornamentation often determines the general shape. Some authors choose to consider ornamentation and shape as one morphological characteristic (e.g., Vinckier \& Smets, 2002a). Nevertheless, we prefer to make a distinction between shape and ornamentation because in some species a very conspicuous ornamentation can be found, e.g., microspines in Cubanola domingensis (Fig. 2G). Another feature that can hamper the designation of orbicule shape is the mutual association of orbicules and their association with the tapetal membrane. When orbicules are aggregated or when they are embedded in the remnants of the tapetum, their individual shape is sometimes difficult to ascertain.

The early diverged taxa all have psilate orbicules and this type represents the ancestral character state (Fig. 5D). Microgranulate orbicules are found in the Spermacoceae alliance (supertribe Rubiidinae, Robbrecht \& Manen, 2006) and orbicules with microspines are present in Hoffmannia, Chiococceae and Spermacoce. In this last group the resemblance between the ornamentation of the orbicules and the sexine is conspicuous (Fig. $2 \mathrm{G}-\mathrm{H}$ ). Orbicules with microspines were until now only known for the Catesbaeeae-Chiococceae-Exostema (CCE) complex (Huysmans \& al., 1999). This character was hypothesized to distinguish the CCE-complex as a monophyletic group. In this manuscript we provide new observations of spiny orbicules in species of different tribes and even of a different subfamily (i.e., Rubioideae). In the subfamily Ixoroideae (supertribe Ixoridinae, Robbrecht \& Manen, 2006) all orbicules have a rough ornamentation besides the plesiomorphic psilate orbicules in the tribes Mussaendeae and Posoquerieae. From the plesiomorphic psilate state, various types of ornamented orbicule types have evolved independently in many clades of the family.

If the orbicular walls of two or more orbicules are fused, the orbicules are described as "aggregated". However, this is not easily detected. The appropriate way to confirm the fusion of orbicular walls is using transmission electron microscopic observations. The characters of embedded orbicules are even harder to observe because of the tapetal remnants covering the inner locule surface. In two species, Anthospermum pachyrrhizum (Fig. 3C) and Ixora borboniae (Fig. 3D), we discovered small threads linking the orbicules. It is unknown if these strands are made up of sporopollenin. In two other species, Payera sp. (Fig. 3E) and Triainolepis africana (Fig. 3F), orbicules are elongated and branched which results in connected orbicules. To our knowledge no similar orbicular organisation has previously been reported. These mutual associations of orbicules and their relation with the tapetal membrane are not depicted on a cladogram because different associations can be found in one specimen.

Huysmans \& al. (1997) recognized four orbicule types based on study of 16 species in one subfamily of Rubiaceae. Two further types were added by Vinckier \& al. (2000) based on study of 12 additional rubiaceous species, and this typology was subsequently applied to other families in Gentianales by 
Vinckier \& Smets (2002a, b, c, 2003). Nevertheless, as noted by these authors not all orbicules can be classified into these types. As argued by Dessein \& al. (2005), data from families throughout the angiosperms are needed to arrive at an orbicule typology that is applicable to all flowering plants.

The correlation of orbicules with tapetum type in Rubiaceae. - Orbicules are inextricably bound up with the tissue from which they originate. Although delineation of the tapetum type of a plant specimen requires developmental data and is therefore seldom straightforward, three basic tapetum types are recognized: (1) parietal, (2) amoeboid and an intermediate (3) invasive non-syncytial tapetum. The positive correlation between orbicules and a parietal tapetum type has been hypothesized for almost a century (e.g., Kosmath, 1927; Ubisch, 1927; Huysmans \& al., 2003; Dessein \& al., 2005). For Rubiaceae, reliable data on tapetum types are very scarce, making it impossible to test this correlation at family level. Nevertheless, because this pattern is confirmed at higher taxonomic levels and in other plant families, we hypothesize orbicule presence to be correlated with the presence of a non-amoeboid tapetum (both type 1 and 3) in Rubiaceae.

Conclusion. - This study adds orbicule data for 64 Rubiaceae species, of which 43 species possess orbicules and 21 lack them. Orbicules are a common feature in Rubiaceae and their presence is plesiomorphic within the family. An evolutionary trend towards less, larger, irregular and ornamented orbicules is demonstrated. The more derived taxa lack orbicules entirely. In general, orbicule characters are constant within genera and tribes, which offers a predictive value for orbicule distribution and a strong phylogenetic signal at these taxonomic levels. The presence of orbicules is hypothesized to be correlated with the occurrence of a non-amoeboid tapetum.

\section{ACKNOWLEDGEMENTS}

We thank Nathalie Geerts (K.U. Leuven) for technical assistance and the curators of the herbarium (BR) and the living collections at the National Botanic Garden of Belgium for the generous supply of anther samples. This research was supported financially by the Research Council of K.U. Leuven (OT/05/35) and the Fund for Scientific Research - Flanders, Belgium (FWO - Vlaanderen) (G.0418.08).

\section{- LITERATURE CITED}

Abadie, M. \& Hideux, M. 1979. L'anthère de Saxifraga cymbalaria L. ssp. heretiana (Boiss.) Engl. \& Irmsch en microscopie électronique (M.E.B. et M.E.T.). 1. Généralités. Ontogenèse des orbicules. Ann. Sci. Nat., Bot., ser. 13, 1: 199-233.

Blackmore, S. 2007. Pollen and spores: Microscopic keys to understanding the earth's biodiversity. Pl. Syst. Evol. 263: 3-12.

Bremer, B. \& Eriksson, T. 2009. Time tree of Rubiaceae: Phylogeny and dating the family, subfamilies, and tribes. Int. J. Pl. Sci. 170: 766-793.

Christensen, J.E., Horner, H.T., Jr. \& Lersten, N.R. 1972. Pollen wall and tapetal orbicular wall development in Sorghum bicolor (Gramineae). Amer. J. Bot. 59: 43-58.

Dessein, S., Ochoterena, H., De Block, P., Lens, F., Robbrecht, E.,
Schols, P., Smets, E., Vinckier, S. \& Huysmans, S. 2005. Palynological characters and their phylogenetic signal in Rubiaceae. Bot. Rev. 71: 354-414.

Echlin, P. 1971. Production of sporopollenin by the tapetum. Pp. 220 248 in: Brooks, J., Grant, P.R., Muir, M.D., Van Gijzel, P. \& Shaw, G. (eds.), Sporopollenin. London: Academic Press.

Echlin, P. \& Godwin, H. 1968. The ultrastructure and ontogeny of pollen in Helleborus foetidus L. I. The development of the tapetum and Ubisch bodies. J. Cell Sci. 3: 161-174.

Endress, P.K. 2003. Morphology and angiosperm systematics in the molecular era. Bot. Rev. 68: 545-570.

Erdtman, G. 1952. Pollen morphology and plant taxonomy: Angiosperms. Stockholm: Almqvist \& Wiksells.

Erdtman, G., Berglund, B. \& Praglowski, J. 1961. An introduction to a Scandinavian pollen flora. Stockholm: Almqvist \& Wiksells.

Furness, C.A. \& Rudall, P.J. 2004. Pollen aperture evolution-a crucial factor for eudicot success? Trends Pl. Sci. 9: 154-158.

Galati, B.G. 2003. Ubisch bodies in angiosperms. Advances Pl. Reprod. Biol. 2: 1-20.

Goloboff, P. 1999. NONA, version 2. Computer program and software. Published by the author, Tucumán, Argentina.

Govaerts, R., Ruhsam, M., Andersson, L., Robbrecht, E., Bridson, D., Davis, A., Schanzer, I. \& Sonké, B. 2010. World checklist of Rubiaceae. The board of trustees of the Royal Botanic Gardens, Kew. http://www.kew.org/wcsp/rubiaceae/ (accessed 3 Dec. 2010).

Halbritter, H. 1998. Preparing living pollen material for scanning electron microscopy using 2,2-dimethoxypropane (DMP) and criticalpoint drying. Biotechnic Histochem. 73: 137-143.

Hesse, M. 1986. Orbicules and the ektexine are homologous sporopollenin concretions in Spermatophyta. Pl. Syst. Evol. 153: 37-48.

Huysmans, S., Dessein, S., Smets, E. \& Robbrecht, E. 2003. Pollen morphology of NW European representatives confirms monophyly of Rubieae (Rubiaceae). Rev. Palaeobot. Palynol. 127: 219-240.

Huysmans, S., El-Ghazaly, G., Nilsson, S. \& Smets, E. 1997. Systematic value of tapetal orbicules: A preliminary survey of the Cinchonoideae (Rubiaceae). Canad. J. Bot. 75: 815-826.

Huysmans, S., El-Ghazaly, G. \& Smets, E. 1998. Orbicules in angiosperms: Morphology, function, distribution, and relation with tapetum types. Bot. Rev. 64: 240-272.

Huysmans, S., Robbrecht, E., Delprete, P. \& Smets, E. 1999. Pollen morphological support for the Catesbaeeae-ChiococceaeExostema-complex (Rubiaceae). Grana 38: 325-338.

Huysmans, S., Verstraete, B., Smets, E. \& Chatrou L.W. 2010. Distribution of orbicules in Annonaceae mirrors evolutionary trend in angiosperms. Pl. Ecol. Evol. 143: 199-211.

Kosmath, L. von. 1927. Studien über das Antherentapetum. Österr. Bot. Z. 76: 235-241.

Moon, H.-K., Vinckier, S., Smets, E. \& Huysmans, S. 2008a. Comparative pollen morphology and ultrastructure of Mentheae subtribe Nepetinae (Lamiaceae). Rev. Palaeobot. Palynol. 149: 174-186.

Moon, H.-K., Vinckier, S., Smets, E. \& Huysmans, S. 2008b. Palynological evolutionary trends within the tribe Mentheae with special emphasis on subtribe Menthinae (Nepetoideae: Lamiaceae). Pl. Syst. Evol. 275: 93-108.

Nagels, A., Muasya, A.M., Huysmans, S., Vrijdaghs, A., Smets, E. \& Vinckier, S. 2009. Palynological diversity and major evolutionary trends in Cyperaceae. Pl. Syst. Evol. 277: 117-142.

Nixon, K.C. 1999. The parsimony ratchet, a new method for rapid parsimony analysis. Cladistics 15: 407-414.

Nixon, K.C. 2002. WinClada, version 1.0. Published by the author, Ithaca, New York, U.S.A.

Punt, W., Hoen, P.P., Blackmore, S., Nilsson, S. \& Le Thomas, A. 2007. Glossary of pollen and spore terminology. Rev. Palaeobot. Palynol. 143: 1-81.

Risueño, M.C., Giménez-Martín, G., López-Sáez, J.F. \& García, M.I.R. 1969. Origin and development of sporopollenin bodies. Protoplasma 67: 361-374. 
Robbrecht, E. \& Manen, J.-F. 2006. The major evolutionary lineages of the coffee family (Rubiaceae, angiosperms): Combined analysis (nDNA and cpDNA) to infer the position of Coptosapelta and Luculia, and supertree construction based on $r b c L, r p s 16$, trnL$\operatorname{trnF}$ and $a t p B-r b c L$ data; A new classification in two subfamilies, Cinchonoideae and Rubioideae. Syst. Geogr. Pl. 76: 85-146.

Rowley, J.R. 1962. Nonhomogeneous sporopollenin in microspores of Poa annua L. Grana Palynol. 3: 3-19.

Schols, P., Dessein, S., D'Hondt, C., Huysmans, S. \& Smets, E. 2002. Carnoy: A new digital measurement tool for palynology. Grana 41: $124-126$.

Ubisch, G. von. 1927. Zur Entwicklungsgeschichte der Antheren. Planta 3: 490-495.

Verellen, J., Dessein, S., Razafimandimbison, S.G., Smets, E. \& Huysmans, S. 2007. Pollen morphology of the tribes Naucleeae and Hymenodictyeae (Rubiaceae-Cinchonoideae) and its phylogenetic significance. Bot. J. Linn. Soc. 153: 329-341.

Verellen, J., Smets, E. \& Huysmans, S. 2004. The remarkable genus
Coptosapelta (Rubiaceae): Pollen and orbicule morphology and systematic implications. J. Pl. Res. 117: 57-68.

Vinckier, S., Huysmans, S. \& Smets, E. 2000. Morphology and ultrastructure of orbicules in the subfamily Ixoroideae (Rubiaceae). Rev. Palaeobot. Palynol. 108: 151-174.

Vinckier, S. \& Smets, E. 2002a. Morphology, ultrastructure and typology of orbicules in Loganiaceae s.l. and related genera, in relation to systematics. Rev. Palaeobot. Palynol. 119: 161-189.

Vinckier, S. \& Smets, E. 2002b. Systematic importance of orbicule diversity in Gentianales. Grana 41: 158-182.

Vinckier, S. \& Smets, E. 2002c. Morphological and ultrastructural diversity of orbicules in relation to evolutionary tendencies in Apocynaceae s.1. Ann. Bot. 90: 647-662.

Vinckier, S. \& Smets, E. 2003. Morphological and ultrastructural diversity of orbicules in Gentianaceae. Ann. Bot. 92: 657-672.

Wiens, J.J. 2004. The role of morphological data in phylogeny reconstruction. Syst. Biol. 53: 653-661.

Appendix. List of taxa investigated in this study. Nomenclatural species names follow Govaerts \& al. (2010). Specimens are ordered alphabetically; living material is indicated with an asterisk $(*)$.

Afrocanthium keniense (Bullock) Lantz, Kenya, Bytebier B. 1884 (BR); Anthospermum pachyrrhizum Hiern, Ethiopia, Puff C., Mantell D. \& Kelbessa E. 811005-4/1 (BR); Antirhea borbonica J.F. Gmel. var. duplidivisa Chaw, Madagascar, Andrianarisata M. 129 (BR); Bertiera angusiana Nittallé, Zambia, Fanshawe D.B. 3683 (BR); Breonadia salicina (Vahl) Heffer \& Wood, Tanzania, Schlieben H.J. 1788 (BR); Calycophyllum candidissimum DC., Mexico, Conzatti C. 4390 (BR); Chamaepentas hindsioides (K. Schum.) Kårehed \& B. Bremer, living material National Botanic Garden of Belgium, accession 19981824-18, collected by Verstraete B., 22.09.2008 (*); Chassalia cristata (Hiern) Bremek., Cameroon, Leeuwenberg A.J.M. 9565 (BR); Chiococca alba (L.) Hitchc., Mexico, Salomon M.J. 1852 (BR); Cinchona calisaya Wedd., D.R. Congo, Robyns W. 931 (BR); Coccocypselum guianense (Aubl.) K. Schum., living material National Botanic Garden of Belgium, accession 19832784, collected by Verstraete B., 22.09.2008 (*); Coffea stenophylla G. Don, cultivated in D.R. Congo, Vermoesen F.M.C. 2182 (BR); Colletoecema dewevrei (De Wild.) Petit, Cameroon, Letouzey R. 11993 (BR); Coprosma tenuifolia Cheesem, New Zealand, Breteler F.J. 13561 (BR); Craterispermum caudatum Hutch, Ivory Coast, Bamps P. 1838 (BR); Cremaspora triflora Hutch \& J.M. Dalz., Sierra Leone, Deighton F.C. 2981 (BR); Cubanola domingensis (Britton) Aiello, living material National Botanic Garden of Belgium, accession 19961234-89, collected by Verstraete B., 22.09.2008 (*); Danais aurantiaca Homolle, Madagascar, Lewis \& al. 1012 (BR); Didymosalpinx abbeokutae (Hiern) Keay, D.R. Congo, Hart T. 851 (BR); Empogona kirkii subsp. junodii (Schinz) Tosh \& Robbr., Mozambique, Gomes A. \& Sousa 3881 (BR); Euclinia longiflora Salisb., Ghana, Jongkind C.C.H. 2197 (BR); Exostema longiflorum (Lamb.) Roem. \& Schult., Cuba, Galeotti H. 1840 (BR); Galium ossirwaense Krause var. ossirwaense, Tanzania, Gereau R.E., Lovett J.C. \& Kayombo C.J. 3761 (BR); Gardenia jasminoides J. Ellis, D.R. Congo, Vanderyst H. 20516 (BR); Geophila afzelii Hiern, Ivory Coast, Tehe G.H. 281 (BR); Guettarda speciosa L., Tanzania, De Marseille 130 (BR); Hamelia patens Jacq., cultivated in Kenya, De Block P., Stieperaere H. \& Muasya A.M. 218 (BR); Hoffmannia refulgens Hemsl., cultivated in the National Botanic Garden of Belgium, De Block P. 1434 (BR); Hymenodictyon floribundum (Hochst. \& Steud.) Robinson, D.R. Congo, Hendrickx L. 4262 (BR); Ixora borboniae Mouly \& B. Bremer, living material National Botanic Garden of Belgium, accession 20040313-16, collected by Verstraete B., 22.09.2008 (*); Ixora finlaysoniana Wall. ex G. Don, living material National Botanic Garden of Belgium, accession 20011837-58, collected by Verstraete B., 22.09.2008 (*); Kraussia floribunda Harv., Mozambique, Zunguze D., Boane C. \& Dunge J. 532 (BR); Luculia gratissima DC., cultivated in the Hortus Botanicus Lovaniensis in Belgium, Martens M. 1932 (BR); Mitriostigma axillare Hochst., living material National Botanic Garden of Belgium, accession 19074051, collected by Verstraete B., 22.09.2008 (*); Morinda citrifolia L., living material National Botanic Garden of Belgium, accession 20061114-59, collected by Verstraete B., 22.09.2008 (*); Mussaenda polita Hiern, Cameroon, Leeuwenberg A.J.M. 8378 (BR); Mycetia malayana (G. Don) Craib, living material National Botanic Garden of Belgium, accession 20021341-56, collected by Verstraete B., 22.09.2008 (*); Oldenlandia corymbosa L., Gabon, Louis A.M., Breteler F.J. \& de Bruijn J. 199 (BR); Ophiorrhiza mungos L., living material National Botanic Garden of Belgium, accession 19981127-00, collected by Verstraete B., 22.09.2008 (*); Oxyanthus unilocularis Hiern, Cameroon, Zenker G. 292 (BR); Paederia cruddasiana Prain subsp. cruddasiana, Tanzania, Greenway P.J. 8322 (BR); Pauridiantha coalescens Ntore \& Dessein, Tanzania, Luke Q., Bytebier B., Butynski T., Ehart C., Perkins A. \& Kimaro G. 6699 (BR); Payera sp., Madagascar, Malcomber S.T. \& Schatz G. \& al. 1281 (BR); Pentagonia tinajita Seem., Ecuador, Clark J.L. 4739 (BR); Posoqueria latifolia (Rudge) Roem. \& Schult., cultivated in the Amani Botanical Garden in Tanzania, Rajabuttirra I. 53 (BR); Pseudomussaenda flava Verdc., living material National Botanic Garden of Belgium, accession 20040495-04, collected by Verstraete B., 22.09.2008 (*); Psychotria kirkii Hiern, Tanzania, Bidgood S., Mbago F. \& Vollesen K. 2301 (BR); Randia sp., Mexico, Hinton G.B. 7894 (BR); Razafimandimbisonia humblotii (Drake) Kainul. \& B. Bremer, Madagascar, Ravelonarivo D. \& Rabesonina R. 514 (BR); Rondeletia purdiei Hook. f., cultivated in the Kisantu Botanical Garden in D.R. Congo, Lejoly J. 700 (BR); Rubia cordifolia L. subsp. conotricha (Gand.) Verdc., Tanzania, Mlangwa J.A. 177 (BR); Sabicea venosa Benth., Ivory Coast, Leeuwenberg A.J.M. 1730 (BR); Saldinia boiviniana (Baill.) Bremek., Comoros, Hoffmann P., Ralimanana H. \& Sifari A.B. 376 (BR); Schumanniophyton magnificum Harms, Ivory Coast, Cremers G. 1176 (BR); Serissa japonica (Thunb.) Thunb., China, Wibbe J.H. 8993 (BR); Spermacoce filituba (K. Schum.) Verdc., Kenya, Drummond R.B. \& Hemsley J.H. 3632 (BR); Stelechantha makakana N. Hallé, Cameroon, Sonké B. 4370 (BR); Stipularia africana P. Beau, Zambia, Marsels F. 35 (BR); Tarenna gracilis (Stapf.) Keay, Sierra Leone, Deighton F.C. 3907 (BR); Triainolepis africana Hook. f. subsp. hildebrandtii (Vatke) Verdc., Kenya, Gillett J.B. \& Kibuwa S.P. 19850 (BR); Uncaria africana G. Don, Cameroon, Sonké B. 3148 (BR); Vangueria agrestis (Schweinf. ex Hiern) Lantz, Togo, Brunel J.F. 7943 (BR); Virectaria procumbens (Smith) Bremek., Liberia, Leeuwenberg A.J.M. \& Voorhoeve A.G. 4662 (BR); Warszewiczia coccinea (Vahl) Klotzsch, Tanzania, Phillipson P.B. 4832 (BR). 